\title{
Хоружий C.C.
}

\section{Исихазм и культура}

Аннотация: На базе развиваемого автором подхода синергийной антропологии и на примере традиции и практики православного исихазма освещается проблема отношений между духовными практиками/традициями и культурными практиками/традициями. Предложена оригинальная концептуализация проблемы в рамках синергийной антропологии, вводящая ряд новых общих понятий, таких как примыкающие и поддерживающие антропологические практики, имманентная культура духовной практики и др. Прослеживается эволюция взаимоотношений исихазма и культуры в истории Византии, с особым вниманием к Исихастскому возрождению 14 в. как выделенному периоду, когда исихазм стал определяющим фактором как на антропологическом, так и на социальном уровне реальности. Методология исследования включает в себя: постановку проблемы, сравнительный анализ, концептуализацию, анализ эволюции взаимоотношений исихазма и культуры. Исторический анализ позволяет сформулировать выводы о предпосылках и перспективах конвергенции, диалога и синергии духовной традиции и культурной традиции в условиях современности. Кроме того, в результате удалось по-новому взглянуть и на эволюцию культуры и, с культурологической точки зрения, охарактеризовать исихазм.

Ключевые слова: Антропология, исихазм, духовная практика, православие, традиция, культура, секуляризация, Византия, Палама, неопаламизм.

Review: The problem of the relationship between spiritual practices/traditions and cultural practices/traditions is investigated in the concrete case of Eastern-Orthodox hesychasm on the basis of the approach of synergic anthropology developed by the author. The framework of synergic anthropology makes it possible to present a self-consistent conceptualization of the problem based on some new concepts such as associated and supporting anthropological practices, immanent culture of spiritual practice, etc. The evolution of the relationship between hesychasm and culture in Byzantine history is reconstructed, with special attention to the phenomenon of Hesychastic renewal of the 14th century which is interpreted as a unique period when hesychasm played the leading role both at the anthropological and social reality levels. The research methodology includes the problem definition, comparative analysis, conceptualization, analysis of the development of the relationship between Hesychasm and culture. The historical analysis has allowed to make a conclusion concerning premises and prospects of the convergence, dialogue and synergy of spiritual traditions and cultural traditions in modern society. Moreover, the results of the research have allowed to see the evolution of culture in a new light as well as to describe Hesychasm from the culturological point of view.

Keywords: Byzantium, Anthropology, Hesychasm, spiritual practice, Orthodoxy, tradition, culture, secularization, Palamas, neopalamism.

Работа выполнена при поддержке РГНФ, проект 14-О3-Оо1о9 «Антроподиагностика современной социальной реальностт на базе синергийной антропологии» (Anthropological diagnostics of Modern Social Reality on the basis of Synergic Anthropology). В основе статьи - лекция, прочитанная на факультете Artes Liberales Варшавского университета, Варшава, май 20142.

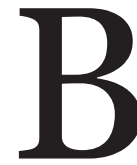

современном меняющемся мире тема «Исихазм и культура» также сильно менялась в своей постановке и своем понимании. Был долгий период, когда изменения были неглубоки; отношение исихастской практики к сфере культуры долгое время мыслилось по одному образцу, который соответствовал общим стереотипам секуляризованного сознания. В кругу этих стереотипов одним из главных и основных всегда являлась оппозициия религии и культуры, причем в составе религии выделялись особо монашество и аскеза: в них видели проявления крайней, фанатичной религиозности, наиболее враждебные культуре, прогрессу и свободе разума. Исихазм же, как древняя аскетическая и монашеская практика, к тому же требующая ухода от социальной жизни и культивирующая непонятные стратегии поведения, странные психотехники, признавался совершенно маргинальным явлением и нередко причислялся к разряду психических анома- 
лий и патологий. Подобное отношение привилось прочно. Оно преобладало даже в самой религиозной среде, не исключая и православный мир. И если бы оно сохранилось до наших дней, то тема «Исихазм и культура» была бы совершенно бессодержательна: нам оставалось бы только констатировать, что исихазм и культура не имеют между собою ничего общего, и их взаимные отношения - это их взаимный антагонизм.

Сегодня, однако, эта рецепция исихазма целиком ушла в прошлое. Многие обстоятельства, многие факторы внесли свой вклад в эту кардинальную перемену. Конечно, прямо и непосредственно новая рецепция создавалась в ходе пристального, углубленного изучения исихазма, которое постепенно стало крупной междисциплинарной областью гуманитарных исследований, включающей проблематику истории и патрологии, богословия, философии, психологии, филологии. Однако само развертывание этих исследований имело необходимою предпосылкой существенные общие сдвиги в духовной и культурной ситуации. Тема «Исихазм и культура» входит как органическая часть в контекст более широкой темы «Религия и культура», и в крупном, отношение к исихазму в обществе и культуре формируют процессы, происходящие в этом широком контексте. В свою очередь, отношения между сферами религии и культуры в современную эпоху определялись ходом глобального процесса секуляризации, который долгое время составлял суть и специфику культурного развития Запада. Начиная с эпох Ренессанса и Просвещения, в этом развитии доминировала тенденция к выделению автономной внерелигиозной сферы в сознании и общественной жизни, а затем к постоянному расширению и усилению этой сферы. Эмансипация безрелигиозного (светского, секуляризованного) сознания постепенно перерастала в экспансию, в конфронтацию с религиозным сознанием и последовательное его вытеснение на периферию, а затем и за пределы публичной жизни, культурного и научного пространства. Процесс секуляризации шел с успехом, и в 20 в. достиг крайних стадий, близких к полному устранению религии и религиозного сознания из публичной жизни. Секуляризм стал признанной и го- сподствующей идеологией на Западе, хотя в разных культурах Запада - в весьма разных формах и в разной степени.

Но в то же время, параллельно с укреплением секуляризма, в самых разных областях начали обнаруживаться и его издержки, негативные стороны и последствия. Доктрина секуляризма руководилась слишком огульными и спорными представлениями о религии, религиозном сознании и их роли для общества и человека. В своих основаниях она была тесно связана с классической метафизикой и классической концепцией человека Аристотеля-Декарта-Канта, и кризис классической метафизики, развернувшийся в 20 в., имел своим следствием и кризис этой доктрины. Воинствующий, радикальный секуляризм исчерпал себя; и хотя явные признания этого, предложения альтернативных концепций начали появляться лишь к концу 20 в., но в разных сферах культуры и публичной жизни уже и раньше возникали феномены и тренды иной природы, которую мы сегодня называем постсекулярной. Один яркий и важный их пример - культура Серебряного Века в России. Эта культура синкретического, Александрийского типа включала в себя множество самых разных течений и направлений, как религиозных, так и светских, которые связывались меж собой, по большей части, отношениями не конфронтации, а плодотворного взаимовлияния и диалога. Одно из главных явлений в ее составе - так называемое Русское Религиозно-философское возрождение: бурное развитие русской философии в конце 19 начале 20 в., которое было инициировано творчеством Достоевского и Владимира Соловьева и в котором рождалось современное осмысление православной традиции, равно обогащавшее и Православие, и философию. В нем стоит особо упомянуть один эпизод, знаменитые Религиозно-философские собрания в Петербурге в 1901-903 гг. Это была большая серия собеседований между представителями Русской Церкви и светскими мыслителями, в которых обсуждались острые и конфликтные проблемы духовно-культурной ситуации страны и сам замысел которых может по праву быть обозначен как встреча религии и культуры. В целом же, по мере развития кризиса секуляризации оппози- 
ция религии и культуры постепенно теряла остроту, пересматривалась и подвергалась переосмыслению. В политической и культурной жизни усиливались явления, которые Питер Бергер квалифицировал как явления десекуляризации и которые позднее были интерпретированы как начинающееся вхождение в парадигму постсекуляризации. В этой новой парадигме, сменяющей парадигму секуляризации, отношения религиозного и секулярного сознания, а также, стало быть, и отношения религии и культуры, переходят от конфронтации к диалогу. Аналогичную эволюцию по-своему проходили и отношения исихазма и культуры.

1. Опишем бегло, как развивалось современное изучение исихазма. Русское Религиозно-философское возрождение питало живой интерес к аскетической традиции Православия, признавая ее значение для склада русского сознания, для народной религиозности. Однако его мыслители не занимались исследованием исихазма и не выдвинули какого-либо его общего понимания; их интерес к православной аскезе выразился лишь в активном увлечении имяславием - недолгим монашеским движением в начале 20 в., которое представляло собой некое маргинальное отклонение от выработанного веками исихастского учения. Здесь еще не было достигнуто цельного видения исихазма как исторического и духовного явления, но тем не менее феномен исихазма в некой мере был вовлечен в поле зрения русской мысли. Продвижение к его новому современному пониманию было продолжено мыслью эмиграции. Важную роль в создании этого понимания сыграло богословское направление, что стало известно как неопламизм, т.е. современная версия учения крупнейшего исихастского богослова св. Григория Паламы (1296-1357). Истоком направления послужили труды молодых богословов русской эмиграции и, в первую очередь, три основоположные работы:

Иеромонах Василий (Кривошеин), «Аскетическое и богословское учение св. Григория Паламы (1936),

В.Н.Лосский, «Очерк мистического богословия Восточной Церкви» (1944),

о. Иоанн Мейендорф, «Введение в изучение св. Григория Паламы» (1959).
На данном этапе наконец происходит пристальное, углубленное обращение к самой почве исихазма, к исихастскому наследию, которое до тех пор оставалось не только мало изученным, но даже неопубликованным в большой части (достаточно указать, что главный, ключевой текст исихастской мысли, «Триады в защиту священнобезмолвствующих» Паламы, был впервые опубликован лишь в 1959 г. Мейендорфом). Как широко известно, неопаламизм привлек к себе многих сторонников во всех странах Православия и вызвал новый подъем православной мысли, став надолго ее ведущим течением (наряду с примыкающим к нему течением неопатристического синтеза, основанным также русским эмигрантом, о. Георгием Флоровским).

Неопаламизм привлек большое внимание к исихазму, и благодаря его многочисленным капитальным разработкам исихастская традиция была прочно признана ядром и стержнем православной духовности. Но хотя он и проник глубоко в паламитское и исихастское богословие, он не создал еще полной современной рецепции исихазма, да и не мог создать таковой, поскольку исихазм отнюдь не является чисто богословским феноменом. Оставался существенный дальнейший шаг: необходимо было подойти к исихазму как к единому явлению во всей совокупности его аспектов и измерений. Исихазм - мистико-аскетическая практика, которая выполняется цельным человеческим существом - интегральным человеком, с вовлечением всех уровней его организации, интеллектуальных, психических и физических. Поэтому путь к его целостному видению могла открыть лишь всесторонняя реконструкция этой интегральной антропопрактики -исихастская антропология, базирующаяся на анализе исихастского опыта. Ее построение было предпринято в моих работах. Для нашей темы сейчас достаточно указать лишь ее главные принципы и установки.

Прежде всего, здесь возникает своя, новая трактовка самой природы исихазма как духовно-антропологического явления. Исихастская практика интерпретируется как некоторый специфический вид «практик себя», в смысле известного понятия, введенного М.Фуко. Согласно Фуко, 
практика себя - это практика самопреобразования человека, которое включает в себя все уровни организации человеческого существа и последовательно продвигается к определенной заранее намеченной цели - некоторому искомому финальному состоянию сознания и интегрального человека. Исихастской же практике соответствует весьма специальный выбор финального состояния (притом такой, который сам Фуко не считал возможным): эта практика направляется к изменению самих фундаментальных предикатов человеческого существования, определяющих способ бытия человека. Такое актуальное трансцендирование человеческого существа исихастский опытный дискурс описывает как встречу энергий человека с энергиями иного, божественного бытия - встречу, в которой достигается согласное соработничество этих онтологически различных энергий (синергия) и восхождение к совершенному соединению всей совокупности человеческих энергий с божественными энергиями (обожение, теозис, совершенная полнота которого остается, однако, недостижимой в пределах здешней реальности). В антропологическом аспекте, важнейшее отличие этой холистической практики - ее конститутивный характер: в опыте восхождения к синергии, а затем к обожению, как опыте встречи с Онтологическим Другим, формируется конституция человека, базовые структуры его личности и идентичности; иными словами, конституируется определенная антропологическая формация. На первый взгляд, этому утверждению о столь фундаментальном антропологическом значении исихастской практики противоречит ее социальная маргинальность, ограниченность малым, узким сообществом. Но надо учесть одну принципиальную особенность этой практики (как и духовных практик других религий): опыт, добываемый ею, является очень выделенным, уникальным, ценным в глазах общественного сознания, и потому ее влияние может быть очень широким, сильным. Создается целый круг самых различных «примыкающих практик», которые ориентируются на исихастскую практику, заимствуют ее элементы. И именно за счет этих примыкающих практик конституция человека, в полноте своей формируемая в лоне исихазма, усваивается, пусть и не в той же полноте, окружающим социумом и оказывается доминирующей в нем антропологической формацией.

С данным антропологическим отличием прямо связано ключевое религиозное отличие: с позиций православного вероучения, опыт исихастской аскезы есть опыт устремления ко Христу и соединения с Ним в Его энергиях, в Духе Святом; и в свою очередь такой опыт рассматривается как квинтэссенция аутентично христианского опыта, жизни в христианской вере. В обретении этого опыта состоят цель и назначение христианской жизни, причем вовсе не только для подвижников-исихастов, но для всех христиан, пусть даже опыт обретается ими не в полноте, а лишь в некой мере, у каждого своей, «елико же вместит». Именно в силу этой квинтэссенциальности исихастского опыта, выделяющей его во всем многообразии религиозного опыта, исихазм приобретает стержневую роль в мире православной духовности и церковности.

Как видно уже из этой краткой характеристики, предложенная трактовка исихазма развивается в постсекулярной парадигме, поскольку сочетает рассмотрение исихазма в религиозно-богословской и в секулярно-научной перспективе (при этом, однако, различая их, а не смешивая и не сливая). В своей полной форме она проявляет этот постсекулярный характер еще сильней, последовательно анализируя аскетические первоисточники, учитывая богословские интерпретации и опираясь на эпистемологические принципы современной философии. В качестве характерной детали можно отметить, например, что изучение структур исихастского опыта показало глубокое родство и сходство между исихастскими техниками внимания и трезвения и механизмами интенционального сознания в феноменологии Гуссерля. Неизбежным образом, в рамках этой современной трактовки исихазма возникает и новая постановка темы об отношениях исихазма со сферой культуры.

2. Для систематического сопоставления двух феноменов следует выработать для их описания единый язык. В синергийной антропологии при анализе процессов культурно-цивилизационного развития 
центральным понятием служит традиция. Я даю этому понятию самую широкую и обобщенную трактовку. Традиция определяется как совокупность трансляций (т.е. актов переноса) в социокультурном пространстве, которая обладает следующими двумя свойствами: 1) содержания входящих в нее трансляций имеют ценность для членов того сообщества, где происходят трансляции; 2) механизмы данных трансляций наделены памятью (т.е. зависимостью от предшествующих трансляций, вносящей связность во всю совокупность их). Культурно-цивилизационный организм включает в себя многочисленные и разнообразные традиции (культурные, религиозные, этнические и др.), и его развитие определяется процессами существования и взаимодействия этих переплетающихся традиций. Разные традиции в разной мере существенны и влиятельны для этого развития, и в ходе него ведущие и доминирующие роли в нем могут, вообще говоря, переходить от одних традиций к другим.

Как ни странно, эти простейшие концептуальные рамки уже позволяют нам вполне содержательно рассмотреть отношения исихазма и культуры. Сфера культуры входит в данные рамки как «культурная традиция», которая в свою очередь представляет собой обширный комплекс-конгломерат разнообразных суб-традиций - научных, художественных, педагогических и т.д. Исихазм также включается в них, ибо с ним тоже связана определенная традиция. Исихазм одинаково часто характеризуют с помощью двух формул, «исихастская практика» и «исихастская традиция», и сейчас нам следует эксплицировать их смысловую связь. Исихастская практика, как мы говорили, это практика себя, индивидуально выполняемая аскетом; тем самым, это - сугубо антропологическое явление. Исихастская же традиция - это сообщество всех адептов исихастской практики и тем самым, социальное явление или точнее, социоисторическое, поскольку сообщество сохраняется, воспроизводя себя в поколениях, в истории. Но это - специфическое социальное явление, включающее в себя существенные антропологические аспекты. Всякая традиция характеризуется, прежде всего, содержанием, которое переносят ее трансляции, и в случае исихастской традиции это содержание есть опыт исихастской практики - опыт антропологический и притом формирующий конституцию человека. Другая базовая характеристика традиции - механизм передачи транслируемых содержаний, и для исихастской традиции таким механизмом служит личное общение, т.е. опять-таки антропологический феномен.

В итоге, исихастская традиция есть явление, которое принадлежит, в нашей терминологии, «интерфейсу социального и антропологчческого»: за счет своей связи с исихастской практикой, она непосредственно передает воздействие антропологических факторов и, прежде всего, конституции человека, на социальном уровне реальности. Далее, нужно учесть всю значительность такого воздействия: по современным представлениям, антропологический уровень глобальной реальности играет ведущую роль в ее развитии, и глобальная динамика определяется антропологической динамикой не в меньшей мере, нежели социальной. Поэтому каналы, инстанции, механизмы, которые репрезентируют антропологическую реальность на социальном уровне, приобретают особую важность; и в ансамбле всех традиций, определяющих развитие глобальной реальности, духовная традиция, передающая конститутивный антропологический опыт духовной практики, должна быть признана ведущей традицией. Однако ведущей традицией не может не быть и культурная традиция. Культурноцивилизационный организм в качестве синонима часто называют просто «культурой», и многочисленные (суб-)традиции, входящие в состав культурной традиции, охватывают все сферы этого организма государство, политику, науку, искусство, образование и др. - образуя полноценную основу его развития. Поэтому в процессе развития любой культуры ведущую роль играют культурная традиция и духовная традиция в их взаимодействии; и в случае Восточно-христианской культуры в качестве духовной традиции въступает исихазм.

Таким образом, тема «исихазм и культура» приобретает принципиальное значение: как мы видим, сопоставляемые феномены представляют собой опреде- 
ленные традиции, которые обе являются ведущими в процессе развития Восточнохристианского культурно-цивилизационного организма. В ходе процесса они неизбежно встречаются, взаимодействуют и между ними складывается некоторое разделение функций. Исихазм, как духовная традиция, определяет антропологические аспекты процесса и, в первую очередь, отвечающую ему парадигму конституции человека, культурная же традиция определяет происходящее в социальных измерениях. Однако весьма существенно, что это разделение лишь указывает преимущественные сферы обеих традиций, но вовсе не означает их ограниченности этими сферами. Исихастская традиция в иные моменты может играть заметную и даже первостепенную роль в социальной реальности, и ниже, прослеживая взаимодействие двух традиций в ходе истории, мы отметим главные из таких моментов. В свою очередь, культурные практики зачастую имеют существенные антропологические стороны: это наглядно видно, например, в педагогических или художественных практиках, и многие социальные практики и традиции также оказывают влияние на антропологическую реальность.

В этой связи стоит указать, что приоритет духовной практики и традиции - в нашем случае, исихазма - в формировании конституции человека нередко оспаривался, в пользу социальных практик, либо художественных практик. В первом случае роль духовной традиции отрицалась с позиций социоцентризма, господствовавших долгое время (в основном, в форме марксизма, но также и в других формах) и очень хорошо известных. Гораздо меньше, однако, обсуждалась позиция, что абсолютизирует роль искусства, утверждая за ним миссию актуального творения высшей реальности и конституирования личности человека. Меж тем, она довольно типична для культуры европейского модернизма и была богато представлена в ней. Она нашла яркое выражение в искусстве русского Серебряного Века - в символизме, в русле, которое называли «теургическими поисками», в творчестве Скрябина, Вяч. Иванова и др. Благодарною почвой для нее был, прежде всего, театр, самое синтетичное из искусств; и несомненно, одним из самых чистых и радикальных опытов ее утверждения является театр Антонена Арто - или точней, феномен Арто во всей его цельности, в его театральных теориях, экспериментах и во всей его трагической жизни.

Сопоставление с этой позицией небесполезно для нас: оно дает возможность увидеть соотношение духовных и культурных практик как некоторую их совместную икономию, согласованное сотрудничество в антропологическом «домостроительстве». С наших позиций, именно в духовной практике - в исихазме, для Восточно-христианского мира - созидается конституция человека, структуры его личности и идентичности, тогда как любые культурные, эстетические, художественные практики не являются конституирующими человека, конститутивными. Но в то же время, они отнюдь не являются непричастными к этим структурам, к конституции человека, напротив, они активно затрагивают их и воздействуют на них. Есть лишь единственное ограничение: они не могут создать их основ, их исходного ядра - именно это составляет исключительную прерогативу духовной практики. В итоге, между двумя видами практик складывается своего рода «разделение труда». Духовная практика, и только она, воспроизводит квинтэссенциальный опыт, в котором актуализуется определенная парадигма конституции человека и создаются основы антропологической формации. Культурные же практики всемерно развивают эти основы: они доставляют сцену, театр, полигон для их испытания и развертывания. При этом, они активно и творчески подходят к ним: раскрывают все их стороны и потенции, артикулируют идентичность человека, проводят своего рода тренинг субъективности, личностных структур, прорабатывают и разрабатывают их до завершенности и полноты. В этих практиках, с их помощью, конституция человека может достигать полной и всесторонней актуализованности, так что человек получает возможность исполниться, сбыться в полной мере - увидеть и понять «истинного себя».

Выполняя данную миссию, культурные практики принимают антропологическую основу, создаваемую в духовной практике. В этом смысле, они ориентируются на духовную практику и потому принадлежат к 
введенной выше категории «примыкающих практик». Но в этой категории они выделены: они не просто зависят от духовной практики, но продолжают ее дело, внося в него собственный ценный вклад. База, создаваемая духовной практикой, развивается в них в самых разных направлениях, так что они распространяют влияние и воздействие духовной практики на разные стороны личности человека и в разные сферы его активности. В них открываются разнообразные, порой неожиданные следствия принципов и установок духовной практики, показывающие все ее культурное и социальное значение. Такие практики, которые базируются на духовной практике, но при этом содержательно дополняют ее, мы называем «поддерживающими практиками». Таким образом, исихастская практика и практики культурные соотносятся между собой как конститутивная антропологическая практика и ее поддерживающцие практики.

Стоит указать, что подобные взгляды на соотношение духовных и культурных практик утверждались и в самой сфере культуры, причем не только в давние эпохи, когда культура находилась в подчинении у религии, но также и в современности. В качестве примера я с удовольствием сошлюсь на Ежи Гротовского, великого театрального новатора 20 в. Гротовский был глубоко близок к Арто, продолжал его идеи, необычайно его ценил - но при всем том он не принимал абсолютизации искусства и театра, которую проповедовал Арто. Приведу небольшую цитату из Гротовского: «Арто мечтал, что новые мифы будут рождаться в театре, но эта прекрасная мечта появилась как результат неточности. Миф формирует основу или рамки деятельности поколений людей... поэтому создание мифа - дело... не театра. Самое большое, на что способен театр - это способствовать кристаллизации мифа» [3, с. 126]. Нетрудно увидеть, что здесь говорится, лишь на другом языке, именно об отношении духовных и культурных практик, и это отношение утверждается точно таким, как в нашей трактовке. На языке Гротовского, «миф» - то же что у нас духовная практика, а то, что он формирует, «основа или рамки деятельности поколений», - это, разумеется, конституция человека. Театр же, по Гротовско- му, не может нести этой конститутивной функции, но может «способствовать кристаллизации мифа», т.е. на нашем языке, артикулируя и обогащая прежде заложенное ядро конституции, он может служить поддерживающей практикой. Так что без всякого сомнения, в вопросе об отношении между духовными и культурными практиками Гротовский наш единомышленник и союзник.

Однако полученные выводы еще далеко не полностью описывают занимающее нас отношение. Опыт нам говорит, что культурные практики вполне могут и не играть роли поддерживающих практик для духовной практики, будь то исихастской или другой; они могут не иметь с нею никакой связи, могут выражать к ней конфликтное, враждебное отношение и т.д. Но это отнюдь не противоречит нашим концепциям. Наши выводы говорят, что культурная практика не является конститутивной, она служит лишь поддерживающей практикой для некоторой конститутивной практики. Однако конститутивная практика - это совсем не обязательно духовная практика. В трактовке синергийной антропологии, человек глубоко плюралистичен: существует целый ансамбль антропологических формаций, каждая из которых соответствует определенной парадигме конституции человека как такового. Исихастская практика отвечает формации Онтологического Человека, которая конституируется в актуализации отношения человека к Богу, в квинтэссенциальном христианском опыте синергии и обожения. Наряду с нею, существуют формации, которые конституируются в актуализации отношения к бессознательному («Онтический Человек»), в выходах в антропологическую виртуальную реальность («Виртуальный Человек»); можно выделить и некоторые другие формации. В любой период истории какая-либо формация является наиболее распространенной, доминирующей, и в ходе истории эти доминирующие формации сменяются. Такая смена составляет антропологическое измерение исторического процесса. В эпоху Нового Времени и Просвещения длительный период доминантности Онтологического Человека, отвечающий примату религии в обществе, подходит постепенно к концу. В минувшем веке доми- 
нирующими формациями служат Онтический Человек, а затем, уже в наши дни, Виртуальный Человек. В свете этой антропологической эволюции понятно, что практики западной культуры, включая и восточно-христианский мир, давно уже выполняют поддерживающую роль, по преимуществу, не для духовной практики, а для других конститутивных практик. (К примеру, не раз упоминавшаяся уже культура модернизма тесно связана с конституцией, индуцируемой из бессознательного.) При этом необходимо еще отметить, что, не имея возможности формировать конституцию человека, культурные практики в то же время обладают свободой и автономией: культурное сознание может развивать поддерживающие практики и для такой парадигмы конституции, которая в данный период не является доминирующей. В этом - одно из выражений свободы художника. Подобные расхождения, конфликты культурных практик и трендов с господствующими формациями уводят эти практики в русло противостояния, протеста и нередко играют важную роль в культурном и социальном развитии.

Теперь наконец отношения исихазма и культуры, духовной практики и культурной практики, очертились более всесторонне. Но они оказываются не очень просты. Культурные практики могут служить поддерживающими не только для конституции Онтологического Человека, но, вообще говоря, для любого типа конституции, в ходе истории они входят в связь с разными такими типами, и во всех этих перипетиях их отношения с исихазмом могут приобретать самый разный характер - от полной поддержки до резкой враждебности. Отсюда следует, что перед нами стоит существенная дальнейшая задача: вслед за описанием отношений исихазма и культуры «в принципе», на концептуальном уровне, мы должны описать их «в реальном времени», проследив, как они менялись в ходе истории. По необходимости, это историческое описание будет самым беглым.

3. Мы последовательно рассмотрим основные этапы исторического пути исихазма. Этап начальный - это зарождение исихастской практики и традиции в раннем монашестве анахоретов Египта и Палестины, начиная с 4 в. Первые отцы-пу- стынники были копты, чаще всего не знавшие ни греческого, ни латыни и чуждые культуре окружающего языческого мира. Нет оснований отвергать обычные оценки этого раннего монашеского движения как внекультурного или контркультурного феномена. Этот прото-исихазм, или «исихазм до исихазма», как иногда называют этот этап, - чисто религиозная и антропологическая практика, дистанцированная от всей сферы культуры. Но в то же время рождающаяся практика холистична и методична, она включает в себя значительные интеллектуальные слагаемые. Бесспорно, исток и стимул исихастской аскезы - аутентичный всецелый порыв человека ко Христу, но очень скоро этот порыв включает в себя представления о том, что в аскезе есть своя мудрость и опыт ее требует истолкования, понимания, рефлексии. В среде анахоретов возникает оригинальный жанр «апофтегм», поучительных миниатюр с афоризмами учителей аскезы и случаями из их жизни. Он полагает начало исихастской литературе, а с нею и культурным измерениям феномена исихазма.

В ближайшие столетия, в 4-7 вв., в ареале Восточного христианства параллельно протекает становление исихастской аскезы и формирование христианской культуры, в составе которой центральное место занимает патристика, богословие Отцов Церкви. Эти два русла развития Восточного христианства устанавливают тесные взаимосвязи, достигая все большего сближения, а затем и синтеза. Является признанным, что в творчестве преп. Максима Исповедника (7 в.) представлен цельный восточно-христианский дискурс - основоустройство определенного типа религиозности, или же способа религиозной жизни, в котором осуществляется синтез патристики и аскетики. Этот синтез выражен очень наглядно в понятии обожения: этот ключевой элемент православной духовности служит одним из базовых понятий патристического богословия и одновременно - высшею целью, к которой направляется исихастская практика; принадлежа, таким образом, обеим сферам, он смыкает их в нераздельное единство. И применительно к отношениям исихазма и культуры, можно говорить, что по мере достижения синтеза патристики и аскети- 
ки, практики формирующейся христианской и воцерковленной культуры становились поддерживающими практиками для формирующегося же исихазма.

Отдельно надо сказать об отношениях исихазма с языческою культурой, ибо в дальнейшем они получают продолжение в отношениях с западной культурой Нового Времени, которая возводила себя к античным корням. Несомненно, ранний исихазм эту культуру отвергал, но было бы неверно тут видеть некую специальную, самостоятельную установку по отношению к культуре: отвержение культуры было лишь частью позиции тотального исхода из мира, разрыва со всем порядком мирского существования. Исихазм утверждает свою инаковость, иноприродность всему этому порядку в целом и не включает в свои принципы отрицания или противостояния каким-либо отдельным его явлениям, областям, аспектам; по отношению к ним действует принцип благого пользования, chresis: в тварном мире ничто не является дурным или добрым само по себе, но все может быть использовано как во благо, так и во зло. Поэтому нужно уточнить нашу характеристику раннего исихазма как «вне- или контркультурного феномена»: по отношению к мирской культуре он выступает не как анти-культурное явление, но как иное этой культуре; и например, его борьба со страстями в человеке - это совершенно не то же что борьба с культурой. В этой связи надо вспомнить, что старая трактовка монашества и аскезы, созданная эпохой Просвещения, приписывает им воинствующе антикультурные позиции, тенденции к подавлению культурного творчества и пресловутый «монашеский обскурантизм». В подкрепление ее обычно также приводится тот или иной набор исторических событий и фактов, таких как убийство мудрой Гипатии толпой фанатиковмонахов в Александрии (415 г.). На все подобные факты в многовековой истории христианского мира заведомо нельзя дать одного общего ответа. Известная часть их, включая и бесчинства фанатиков в Александрии, выражает проявления страстей, т.е. извращения исихастской практики и отклонения от ее пути. Но в большинстве своем они вообще не принадлежат к истории исихазма, и наш анализ ясно показы- вает, что по меньшей мере для этой истории указанная старая трактовка является поверхностной и неверной.

На следующих этапах, продолжая формирование своего метода и органона, исихазм занимает определенное положение в религиозной, культурной, социальной жизни Византии. К основным характеристикам этого положения принадлежат его отношения со сферой культуры, а также еще с одним влиятельным руслом византийской религиозности, которое было унаследовано ею от языческого теократического сознания Древнего Рима. Это русло, которое я называю руслом сакрализации, несло, в первую очередь, миссию сакральной легитимации императорской власти и выражало языческую установку сакрализации, утверждающую прямую причастность Божественному каких-то явлений или вещей здешнего мира. Исихастская практика восхождения к обожению не включает в себя этой установки, образуя другое религиозное русло, которое естественно называть руслом обожения; так что в любой период духовно-культурная ситуация в православных обществах определялась, прежде всего, отношениями между руслом обожения, руслом сакрализации и сферой культуры. Особенностью византийской культурной традиции была ее гетерогенность: в нее изначально вносили свой вклад, очень разный, все три истока византийской цивилизации: христианская вера, культура античной Греции и римская государственность, а позднее сюда добавились еще влияния латинского Запада. В сложном балансе всех этих слагаемых и складывались отношения исихазма с византийской культурой. Разумеется, как и на Западе, тут не мог не возникнуть феномен «монастырской культуры». Все формы ее, известные в культуре западного Средневековья, здесь присутствовали также: создание аскетических и богословских текстов, монастырские школы, скриптории, книжные собрания. Параллелизм с западной традицией был значителен, и он включал не только эти внешние, материальные формы. В ряде католических орденов - в ирландском монашестве, у картузианцев, камальдулов и др. - культивировались практики, упражнения, аскетические распорядки, близкие к отдельным элемен- 
там и сторонам исихастской практики. Широкую популярность получила парадигма ступенчатого выстраивания духовных трудов, почерпнутая из исихастского трактата св. Иоанна Лествичника (7 в.), на Западе создавались ее различные варианты (например, в «Лествице затворников» Гвиго Второго Картузианца (12 в.)). Но в целом, исихазм как духовно-антропологический феномен, заключающий в себе полный органон восхождения человека к соединению с Богом, всегда сохранял свою уникальность и глубокие отличия от всех западных школ, как сущностные, так и типологические.

Во всей полноте и своеобразии исихазм сумел осуществить себя в Византии 14 в., в период, получивший название Исихастского возрождения. Это - выделенный, исключительный эпизод во всей его многовековой истории, а для нас - редкий пример, в котором мы можем увидеть реально воплощенными почти все возможности и стороны феномена духовной практики и традиции. Прежде всего, в этот период исихастская практика наконец завершает свою тысячелетнюю работу по созданию органона исихастского опыта (полного свода или канона правил организации, проверки и истолкования этого опыта). На завершающей стадии в центре ее внимания высшие ступени Лествицы духовного восхождения - подступы к обожению, которые исихасты воспринимают и квалифицируют как «созерцание Фаворского Света», иными словами, как тот же опыт, что испытали ученики Христа в событии Преображения на Фаворе. Это - опыт актуального Богообщения, созерцания-соединения со Христом, и свидетельства подвижников о нем имеют особое отличие: будучи прямым поведанием лично испытанного опыта «вещей Божественных», они представляют собой не что иное как богословие, как оно издавна понималось в исихазме и православии. Таким образом, на этой стадии исихазм развивает собственный богословский дискурс, передающий его аутентичный опыт (хотя элементы исихастского богословия, конечно, появлялись и много раньше). Богословие Божественных энергий св. Григория Паламы существенно углубило православный синтез патристики и аскетики. Оно было рассмотрено и одобрено на Поместном соборе 1351 г. и тем самым опыт исихазма получил свое закрепление в догматах православного вероучения.

Достижение полной зрелости исихазма, исполнение основных внутренних заданий исихастской практики не могли не сказаться и на внешнем положении исихастской традиции, на ее отношениях с окружающею реальностью. Исихастское возрождение 14 в. - исключительный эпизод в истории не только исихазма, но и всей Византии: sui generis духовный взрыв, когда аскетическое искусство, практикуемое малым замкнутым сообществом, отдалившимся от социума, вдруг сделалось центром всей жизни этого социума. Исихастская традиция выходит в мир. Вначале принципы исихастской аскезы и обоснование их у Паламы активно оспаривались, и около двух десятилетий в середине 14 в. в Византии шли «Исихастские споры»- ожесточенная полемика, захватившая не только церковномонашеские круги, но и все общество, которое разделилось на два лагеря, сторонников и противников исихазма и Паламы. С победой исихастов в этой полемике, закрепленной Собором 1351 г., влияние исихазма быстро распространяется во всех направлениях, во все слои общества и все сферы византийской жизни, включая дворцовые и официальные круги, области политики, управления, в некой мере, даже имущественных и правовых отношений. В религиозной жизни русло исихастской духовности, русло обожения, явно преобладает, меж тем как конкурирующее русло сакрализации остается на втором плане. Широта влияния исихазма беспрецедентна и уникальна - большинство практик, что формируют культурно-цивилизационный организм Византии, в этот период становятся, в наших терминах, поддерживающими практиками исихазма. И, разумеется, в их спектре важнейшее место занимают культурные практики. В эту исключительную эпоху взаимодействие исихазма и культуры охватывает все сферы культуры, оно глубоко и активно как никогда. В церковном искусстве исихастские влияния выражаются в целом комплексе характерных особенностей, мотивов, которые быстро укореняются не только в Византии, но по всей православной ойкумене. Эти влияния сохраняются надолго 
и по сей день составляют особую область изучения для искусствоведов. - В итоге, исихазм предстает уже далеко не только как искусство молитвы и практика себя, он выступает как целостный способ существования христианского человека и в потенции, даже общества. Исихастское же возрождение осталось в истории как незаменимый образец, показывающий, что такое исихазм в полноте его выражения.

4. Упадок и крах Византийской Империи - непреодолимые причины, в силу которых Исихастское возрождение не могло получить развития. Дальнейшие страницы в истории традиции связаны, в первую очередь, с Россией. Русский религиозный менталитет изначально обнаруживает в себе сильную аскетическую струю, и в зачаточных формах, напоминающих прото-исихазм отцов-пустынников, исихазм появляется на Руси уже вскоре после ее Крещения. В Киевской Руси как духовная традиция, так и культурная традиция представлены лишь ранними и неполными формами, и в соответствии со средневековой моделью, культурная традиция находится под эгидой духовной и религиозной традиции, развиваясь в их лоне. Наряду с летописями, к самым ранним памятникам оригинальной русской литературы принадлежат патерики, один из классических жанров раннеисихастского текста; в сказаниях о киево-печерских подвижниках 11-12 вв., mutatis mutandis подобных «апофтегмам» египетских анахоретов 4-5 вв., тема «исихазм и культура» начинает получать свое наполнение на русской почве. Русло сакрализации в составе религиозной традиции в эту эпоху пребывает мало востребованным и мало развитым, поскольку слаборазвитые институты княжеской власти не могут ставить всерьез задач своей сакральной легитимации. И в целом, можно считать, что Киевское христианство развивалось по преимуществу в исихастском русле обожения, а отношения русского (прото-) исихазма с зарождающейся культурной традицией соответствовали модели поддерживающей практики. Но стоит также отметить, что на этом этапе русская религиозность и, в частности, русский исихазм еще не обнаруживают каких-либо крупных оригинальных черт, не складываются в явление с некой новой, самостоятельною природой.

На следующем этапе, в эпоху Московской Руси, такие оригинальные черты возникают. Формируется специфический вариант, извод восточно-христианского дискурса, многие особенности которого, привившись и закрепившись, продолжают определять русское сознание и действительность по сей день: Москва стала судъбой России. Русский исихазм и его отношения с русской культурой играют крупную роль в сложных путях Москвы, и на протяжении эпохи Московской Руси эти отношения меняются радикально. Определяющий фактор и вектор развития Москвы - неуклонное усиление Власти, от княжеской через великокняжескую и царскую - к имперской. Это усиление рождает запрос на сакральную легитимацию Власти и тем самым, на сакрализацию в религиозной сфере. На жизнь религии, на органику духовной сферы налагается заказ Власти, который передается путем давления, пресловутого «административного ресурса». С неуклонным усилением Власти, столь же неуклонно растет давление - и в результате, определяющий фактор эволюции религиозной традиции в Московской Руси - это непрестанный рост ее подчинения Власти, государству, и вызываемый этим рост сакрализации, достигающий в конце концов самых гипертрофированных масштабов. Исихастское же «русло обожения» при этом неизбежно вытесняется и маргинализуется.

Проследим важнейшие вехи этого процесса. Начало возвышения Москвы - 1415 вв., время преподобных Сергия Радонежского и Андрея Рублева. Эти фигуры знаковые для русской духовности и культуры, с ними связаны вершинные достижения страны. Вышеуказанный «определяющий вектор»- еще не определяющий, он только намечается и сквозит. Главное же содержание периода совсем иное. В религиозной жизни преобладает «русло обожения», через активные связи с Византией, как и через южнославянское посредничество (феномен «Второго южнославянского влияния») эта жизнь впитывает воздействия Исихастского возрождения. Преп. Сергий инициирует широкое, мощное монашеско-монастырское движение, приводящее к появлению на лесных 
пространствах северной Великороссии так называемой «Русской Фиваиды»- обширного духовного очага из сотен больших и малых обителей, где практика хотя и не следовала строго исихастскому органону, но в разной мере ориентировалась на него, была «поддерживающей практикой» исихазма. Творчество Рублева, Феофана Грека и других мастеров демонстрирует наличие исихастских влияний в русском искусстве, подобных аналогичным влияниям в искусстве Византии и Балкан. Культурная традиция продолжает пребывать в лоне духовной традиции, но стоит отметить, что даже в пору близких контактов с кругами Исихастского возрождения, на Руси практически не усваиваются и уж тем паче не приумножаются (хотя отчасти и переносятся сюда: различие между «трансляцией» и «рецепцией») богословско-философские труды исихастов, паламитское богословие.

Период решающих перемен - это 16 век, «век великого перелома», если перефразировать сталинскую формулу. Именно тогда совершается лавинное нарастание сакрализации. Оно многосторонне. Прежде всего, интенсивно развертывается сюжет сакрализации власти, который следует логике известного феномена translatio imperii. Еще в 15 в. заключается брак Ивана III с Софией Палеолог, выдвигается концепция «Москва - Третий Рим» (ок. 1523-1524), Москва становится патриаршим престолом (1589), в Москву доставляются символические знаки византийской государственности. Власть московских государей включается в цепь преемственности священных царств - и соответственно, должна получать надлежащее сакральное обеспечение, которое и начинает создаваться. Отношения Церкви и Власти неизбежно переосмысливаются и переформатируются в духе византийской идеи симфонии священства и царства; возникают соответствующие построения политической теологии и церковных церемониалов (например, чин венчания Ивана IV (1547)). Наряду с этим сакрализация на Руси активно развивается и еще в одном русле, уже не транслированном из Византии, а автохтонном: она также находит выражение в непомерном разрастании сферы обрядности, в господстве обрядово-ритуалистической религиозности.
Это тоже языческая религиозность, но связанная уже не с сакрализацией власти, a со стихией пережитков архаической народной религии. Она всегда имела стойкие корни в русском сознании, и в 16 в. ее влияние, весьма усилившись, привело в жизни Церкви к тренду, известному как «догматизация обряда». То была тенденция наделять статусом церковного догмата, сакральным статусом, все большее число церковных обрядов, деталей богослужения, а затем и простых обычаев: догматизация обряда снимала грань между обрядом и догматом и смыкалась с ритуализацией повседневности, сакрализацией быта. Полным торжеством этой тенденции стал так называемый Стоглавый Собор в Москве (1551). Последовательно осуществленная им догматизация обряда одновременно укрепляла тенденции к сакрализации быта и означала победу, нормативное закрепление установок ритуальной неподвижности, инертности, косности во всех сферах жизни.

Понятно, что это огромное разрастание русла сакрализации вело к вытеснению, маргинализации исихастского русла обожения. Помимо того, на ситуации русского исихазма весьма губительно сказался так называемый «спор нестяжателей и иосифлян», полемика двух монашеских группировок о монастырском землевладении. К нестяжателям, стоявшим против такого землевладения, принадлежали «заволжские старцы», монахи строго исихастского направления, лидером которых был св. Нил Сорский (ок.1433-1508), крупнейший учитель исихазма и автор первого русского исихастского трактата «Предание ученикам». Спор завершился их поражением, и хотя позиции исихазма сами по себе не подвергались в нем критике, последовавшие гонения на нестяжателей довольно быстро привели исихастскую традицию на Руси к полному упадку.

Описанные процессы вели к оригинальному состоянию культурно-цивилизационного организма. В его развитии, как мы говорили, играют ведущую роль духовная традиция и культурная традиция. В Московской Руси духовная традиция вытеснялась установкой сакрализации и приходила в упадок. Что же до культурной традиции, то в ее судьбе отразились глубокие различия между явлениями са- 
крализации в Византии и России. Византийская религиозность также была сильнейше сакрализована, однако сакрализация по-византийски, какою ее внедрял, скажем, Юстиниан, включалась в контекст высокоразвитой культуры имперского и церковного символизма, по-своему даже обогащая этот контекст. Но сакрализация по-московски, по Стоглаву, направлялась к неподвижному, тотально сакрализованному и ритуализованному существованию, которое исключало всякое развитие, всякую культуру. И можно сказать, пожалуй, что в Москве наметилось собственное оригинальное решение проблемы «исихазм и культура»: ни исихазма, ни культуры.

Столь радикальное решение не было, однако, реалистичным, поскольку существование культурно-цивилизационного организма без культуры, притом отвечающей своему времени, невозможно технически. И в условиях, когда развитие из собственных духовно-культурных основ оказалось заблокированным - ибо эти основы стали зоной сакральной неприкосновенности и неподвижности - оставалась единственная стратегия выживания: вестернизация, т.е. заимствование всех необходимых элементов современной культуры с Запада. В ограниченной мере эта стратегия проводится уже в 17 в., а с началом 18 столетия Петр Великий принимается ее осуществлять с небывалой энергией и размахом. Так наступает эпоха Имперской России. Для культурной традиции это - эпоха расцвета и кульминации, высших достижений, которые ставят Россию в ряд ведущих европейских культур. Однако и для духовной традиции, для русского исихазма, это также период высокого подъема и плодотворного развития, рождения новых творческих форм. Обе традиции сумели успешно преодолеть те тупики, в которые увлекали их тенденции Московской Руси. Но есть важная особенность этого преодоления: на том новом этапе, в который теперь входят духовная традиция и культурная традиция, они существуют и развиваются совершенно раздельно, у них нет не только никаких отношений меж собой, но даже простого знания друг о друге. В первые десятилетия 19 в. исихастская аскеза возвращается постепенно в Россию, отчасти заново зарождаясь в народной среде, а от- части транслируясь из-за рубежа, из монастырей Молдавии, благодаря ученикам преп. Паисия Величковского (1722-1794) и выпущенной им книге «Добротолюбие» (1793), капитальному компендиуму классических исихастских текстов. Крупнейшей фигурой, как бы символизирующей это возвращение традиции и ее подъем, является св. Серафим Саровский (17591833). В это же время чрезвычайно активизируется жизнь русской литературы, поэзия достигает ранее небывалого уровня, так что период 20х-30х гг. 19 в. поздней получил название Золотого Века русской культуры. В этом культурном подъеме также выделяется крупнейшая фигура, как бы символизирующая все его свершения, весь масштаб, - фигура Пушкина. И по давно сделанному наблюдению, эти два великих современника верней всего не знали о существовании друг друга.

Эта раздельность продолжается на протяжении почти всей эпохи, даже тогда, когда и духовная и культурная традиция поднимаются к своим высшим достижениям, имеющим мировую значимость. С середины 19 в. складывается классическая русская литература, приобретающая известность во всем мире, а в России несущая не только художественную, но и духовно-воспитательную миссию, служащая объединяющим центром и школой национального сознания. В то же время исихастская традиция в России достигает расцвета, вступая в новый период, который нередко называют Русским исихастским возрождением. Появляются крупнейшие учители исихазма - свв. Феофан Затворник (1815-1894), Игнатий Брянчанинов (1807-1867), выделяются очаги, где углубленно культивируется искусство Умного Делания. Возникает и важное новое явление в русле древней традиции - русское старчество. Суть его в том, что отдельные многоопытные подвижники-исихасты принимают на себя особое служение духовного руководства, совета, помощи живущим в миру - вообще говоря, всем, кто в том мог нуждаться. Здесь традиция, в начале своем требовавшая строгого ухода от мира, совершала возврат в мир, открывала новые формы общения и стратегии социализации. Движение старчества встречает живейший отклик в обществе, становится заметным явлением русской 
жизни - и на гребне его известности наконец начинается и процесс сближения русского исихазма с культурной традицией. Крупнейший знак этого сближения - роман «Братья Карамазовы», где Достоевский, взяв за образец великого оптинского старца Амвросия (Гренкова, 18121891) и его служение, стремится показать стержневую роль и решающее значение исихастской духовности в складе русского сознания и в судьбах России. Другой, не меньший знак - сама Оптина как притягательный центр, топос встречи русского исихазма и русской культуры: начиная с Гоголя и славянофилов в 40х гг. 19 в. и заканчивая символистами в $20 x$ гг 20 в., уже после закрытия обители большевиками, сюда стремилось множество творческих людей, кому Россия обязана лучшими плодами своей культуры.

Однако процесс сближения был не быстр и не легок. По-своему, но Россия тоже шла в общем тренде секуляризации, и в крупном, начиная с Петра, ее культура всегда оставалась вестернизованной, следуя в фарватере западного культурного процесса. Ситуация религии в целом определялась Синодальной Церковью, строй которой возник в итоге радикальной реформы Петра и вызывал массовое отталкивание и протест, отход от Церкви. Исихастское же возрождение в России было по преимуществу феноменом низовой, народной религиозности, и даже во время него духовная традиция почти не актуализовала заложенных в ней культурных потенций (в чем было одно из существенных различий между двумя возрождениями, как равно и в целом между русским и византийским исихазмом). Встречное движение культуры также не имело особой силы, и «Братья Карамазовы» являются скорей исключением, подтверждающим это правило. Поэтому разделяющая дистанция была велика. Как отмечалось в начале, культура Серебряного Века, Религиозно-философское возрождение еще не открыли для себя мир исихазма - их единственною попыткой вхождения в этот мир стало увлечение имяславием, которое отнюдь не привело к адекватному пониманию исихазма. Тенденция к сближению была несомненной, но она не успела принести заметных плодов к тому рубежному моменту, когда большевистская револю- ция резко оборвала духовно-культурный процесс в стране.

5. «Разрывы и связи»: такою формулой о. Георгий Флоровский определил специфический характер российского духовнокультурного развития. Большевистская революция и советский строй принесли, несомненно, один из самых радикальных разрывов. Духовная и культурная история России вступили в период затяжной и тяжелой деградации, которая, меняя фазы и формы, длится до сего дня. И русскому исихазму, и русской культуре пришлось пройти через годы выживания и сопротивления, катакомбного существования. Однако в рассеянии их жизнь продолжалась, и в их отношениях были даже достигнуты успехи. Как мы отмечали, для русского исихазма было всегда типично известное невнимание к богословскому измерению исихастской практики, отсутствие усвоения - не говоря уж о дальнейшем развитии - богословского осмысления исихастского опыта в паламитском богословии Божественных энергий. В эмигрантский период эта черта была преодолена. Как мы уже сказали в начале, богословы русской эмиграции стали основателями неопаламизма, и для темы «исихазм и культура» важно, что в круг ведущих авторов современного энергийного богословия входят и сами монахи-исихасты, подвизавшиеся на Афоне, - архиеп. Василий (Кривошеин) и игумен Софроний (Сахаров).

В целом же, из нашего обозрения уже вырисовывается общая картина темы. Как мы могли убедиться, отношение исихазма к культуре включает два разных русла. Прежде всего, это - отношение к мирской культуре, и непосредственно - к культуре того общества, в котором существует - пускай и отделяясь от него - подвижническая традиция. Его мы и прослеживали, главным образом, в нашем обозрении; но кроме этого очевидного русла, есть еще и другое. Феномен исихазма, исихастская практика и традиция, несут в себе определенные собственные культурные аспекты, культурные потенции. Исихастская практика включает в себя рефлексию, и целый ряд элементов ее органона - таких как, скажем, истолкование опыта - представляют собой интеллектуальные и культурные практики. В определенном смысле и 
богословие представляет собою часть исихастской практики, ибо в православии широко принята упомянутая уже выше трактовка богословия как прямого поведания личного опыта Богообщения, каким оно достигается на высших ступенях исихастской Лествицы. В силу этого есть основание утверждать, что существует явление, которое можно назвать имманентной культурой исихазма и которое можно определить как актуализацию культурных аспектов и потенций, заложенных в исихастской практике и традиции. (Заметим попутно, что аналогичное явление можно сопоставить всякой духовной практике.) Понятие имманентной культуры исихазма близко к введенному выше понятию поддерживающей практики и полезно дополняет его: поддерживающая практика, ориентируясь на исихазм и сближаясь с ним, принадлежит все же к секулярной, мирской культуре.

Укажем для примера некоторые феномены и эпизоды, в которых находит выражение имманентная культура исихазма. В первую очередь, это, разумеется, создаваемая исихазмом литература - богатейший корпус текстов, венчаемый - но отнюдь не заканчиваемый! - «Добротолюбием». Затем сюда следует относить синтез аскетики и патристики: образуя синтез с патристикой, аскетика обнаруживает в себе элементы, общие или родственные с патристическим богословием. Как мы замечали, важным таким элементом служит дискурс обожения; можно также считать, что аскетическое богословие преп. Максима Исповедника в целом принадлежит к имманентной культуре исихазма. Бесспорно, к ней же принадлежит и следующий, паламитский синтез православной мысли: в богословии Паламы и во всем византийском Исихастском возрождении имманентная культура исихазма сумела выразить себя в весьма значительной меpe (в отличие, увы, от Русского исихастского возрождения, куда менее многостороннего). Далее, при распространении исихазма на Балканы и Русь возникает весьма примечательное явление аскетико-филологической школь: когда сообщество монахов-исихастов осуществляет филологические труды по сбору, текстологическому анализу, переводу и публикации исихастских рукописей. Главными были три школы в разных странах: Тырновская литературная школа в 14 в. в Болгарии, школа преп. Паисия Величковского в Молдавии в 18 в. и русская школа в Оптиной Пустыни в 19 в. Деятельность таких школ - яркий пример имманентной культуры исихазма. Ясно, что они тесно связаны с руслом «монастырской культуры»: можно сказать, что аскетико-филологические школы - это специфически исихастская форма монастырской культуры, отличающаяся тем, что как задачи, так и вся деятельность этих школ подчинены исихастской практике и в нее интегрированы. Сама по себе монастырская культура также, конечно, принадлежит имманентной культуре исихазма (а на Западе - к имманентной культуре католического монашества).

Плоды трудов исихастских филологических школ были очень значительны. Достаточно сказать, что в школе преп. Паисия было создано славянское «Добротолюбие», появление которого пробудило широкое духовное движение во всем православном мире - движение, получившее название Филокалического возрождения и в некой мере не угасшее по сей день. Культурные практики, развиваемые в русле Филокалического возрождения, в известной части можно также относить к имманентной культуре исихазма, а в целом для их ансамбля характерно сближение и сотрудничество, своего рода конвергенция практик светской культуры и имманентной культуры исихазма. Подобная конвергенция или, в широком смысле, синергия, еще более характерна для современного неопаламитского богословия: как мы говорили, в его русле мысль светских ученых и монахов-исихастов развивается в нераздельном единстве. И такое же единение можно наблюдать в культурной работе, что ведется на современном Афоне.

В этом явлении конвергенции отношения исихазма и культуры, духовной традиции и культурной традиции, приобретают форму сотрудничества и диалога [2; 3]. Для современности это характерно: возвращаясь к началу, мы можем вспомнить о переходе современного мира в постсекулярную парадигму, в фазу постсекулярного диалога. Формируя новую конфигурацию отношений между секу- 
лярным и религиозным сознанием, современная ситуация приносит и новые возможности сближения между светской культурой и имманентной культурой исихазма. И можно питать надежду, что в подобном сближении, ведущем к творческой синергии двух разных типов культуры, открывается перспектива плодотворного существования духовной традиции в современном обществе.

\section{Библиография:}

1. Хоружий С.С. Исследования по исихастской традиции. Тт 1,2. СПб., Изд-во Русской христианской гуманитарной академии, 2012.

2. Хоружий С.С. Опыты из русской духовной традиции. М., Изд-во Парад. 2005.

3. Гротовский Е. К Бедному театру. М., 2009.

4. Т.П. Берсенева Феномен синергии в древнерусской культуре // Философия и культура. - 2013. - 9. - C. 1217 - 1223. DOI: 10.7256/1999-2793.2013.9.9281.

5. Берсенева Т.П. Синергия. Синергетика. Диалектика. // Человек и культура. - 2013. - 5. - C. 35 - 46. DOI: 10.7256/2409-8744.2013.5.9526. URL: http://www.e-notabene.ru/ca/article_9526.html

6. Кочерова А.В. Система сакрализации базовых идеалов культуры Византии на основе анализа трактата Михаила Пселла «Слово на Благовещение Пресвятой Богородицы» (XI век) // Социодинамика. - 2015. 4. - C. 49 - 63. DOI: 10.7256/2409-7144.2015.4.15048. URL: http://www.e-notabene.ru/pr/article 15048.html

\section{References (transliterated):}

1. Khoruzhii S.S. Issledovaniya po isikhastskoi traditsii. Tt 1,2. SPb., Izd-vo Russkoi khristianskoi gumanitarnoi akademii, 2012.

2. Khoruzhii S.S. Opyty iz russkoi dukhovnoi traditsii. M., Izd-vo Parad. 2005.

3. Grotovskii E. K Bednomu teatru. M., 2009.

4. T.P. Berseneva Fenomen sinergii v drevnerusskoi kul'ture // Filosofiya i kul'tura. - 2013. - 9. - C. 1217 - 1223. DOI: 10.7256/1999-2793.2013.9.9281.

5. Berseneva T.P. Sinergiya. Sinergetika. Dialektika. // Chelovek i kul'tura. - 2013. - 5. - C. 35 - 46. DOI: 10.7256/2409-8744.2013.5.9526. URL: http://www.e-notabene.ru/ca/article 9526.html

6. Kocherova A.V. Sistema sakralizatsii bazovykh idealov kul'tury Vizantii na osnove analiza traktata Mikhaila Psella «Slovo na Blagoveshchenie Presvyatoi Bogoroditsy» (XI vek) // Sotsiodinamika. - 2015. - 4. - C. 49 - 63. DOI: 10.7256/2409-7144.2015.4.15048. URL: http://www.e-notabene.ru/pr/article_15048.html 